\title{
Corynebacterium minutissimum sp. nov., nom. rev.
}

\author{
MATTHEW D. COLLINS ${ }^{1}$ AND DOROTHY JONES ${ }^{2 *}$
}

Department of Microbiology, National Institute for Research in Dairying, Shinfield, Reading RG2 9AT, ${ }^{1}$ and Department of Microbiology, School of Medicine and School of Biological Sciences, University of Leicester, Leicester LEI $7 R H_{,}{ }^{2}$ United Kingdom

\begin{abstract}
"Corynebacterium minutissimum" Sarkany, Taplin, and Black 1962 was not included on the Approved Lists of Bacterial Names and consequently has no standing in bacteriological nomenclature. However, the results of numerical taxonomic, cell wall, lipid, and deoxyribonucleic acid base composition studies indicate that the organism designated the type strain by Sarkany et al. (strain NCTC 10288) and other strains studied by these workers form a distinct taxon within the genus Corynebacterium. The name Corynebacterium minutissimum is here revived for the same organism to which the name was applied by Sarkany et al. The type strain is strain NCTC 10288 .
\end{abstract}

The name "Corynebacterium minutissimum" was proposed by Sarkany et al. (8) for the causative agent of erythrasma in humans (7-9). However, this name was omitted from the Approved Lists of Bacterial Names (10) and therefore lost standing in bacterial nomenclature. This is unfortunate because numerical taxonomic and chemical studies (1-6) have indicated that "C. minutissimum" NCTC $10288^{\mathrm{T}}$ ( $\mathrm{T}=$ type strain), NCTC 10284, and NCTC 10285 comprise a distinct species in the genus Corynebacterium. Therefore, we revive the name Corynebacterium minutissium and provide a complete description of this organism.

Description of Corynebacterium minutissimum sp. nov., nom. rev. The following description is based on a number of studies $(1-9,11)$ and our own observations on strains NCTC $10288^{\mathrm{T}}$, NCTC 10284, and NCTC 10285.

Surface colonies on blood agar are circular, about $1 \mathrm{~mm}$ in diameter, low convex with entire margins, and not pigmented; the surfaces are shiny and moist. When grown on certain rich media (e.g., media supplemented with $20 \%$ [vol $/$ vol] fetal bovine serum), colonies show a coral red to orange fluorescence under Wood light $(365 \mathrm{~nm})$. Gram strains of exponential-phase cultures show straight to slightly curved rods which exhibit some pleomorphism. Cells occur singly or are arranged at right angles to give $\mathrm{V}$ formations; palisading occurs. The lengths of the rods range from 1 to $2 \mu \mathrm{m}$, and the diameters range from 0.3 to $0.6 \mu \mathrm{m}$. Nonmotile. No endospores are produced. Nonhemolytic. Optimum growth temperature, 35 to $37^{\circ} \mathrm{C}$. Not heat resistant. Facultatively anaerobic. Catalase and cytochromes are produced. Acid without gas is produced from glucose, fructose, mannose, and maltose. Some strains (including strain NCTC
$10288^{1}$ ) produce acid from sucrose. No acid is produced from lactose, raffinose, or xylose. Methyl red and Voges-Proskauer negative. Indole is not produced. Sodium hippurate is hydrolyzed. Phosphatase and deoxyribonuclease are produced. Pyrazinamidase positive. Urease is not produced. Gelatin and casein are not hydrolyzed. Nitrate is not reduced.

The cell wall peptidoglycan contains mesodiaminopimelic acid; alanine and glutamic acid are also present. Arabinose and galactose are the wall sugars. Short-chain mycolic acids ( 28 to 36 carbon atoms) are present. Long-chain nonhydroxylated fatty acids are primarily of the straight-chain saturated, monounsaturated (oleic acid series), and 10-methyl branched types. Major cellular fatty acids are hexadecanoic, octadecenoic, and 10-methyl octadecanoic acids. Major menaquinone components are $\mathrm{MK}-9\left(\mathrm{H}_{2}\right)$ and MK- $8\left(\mathrm{H}_{2}\right)$. The polar lipids are diphosphatidylglycerol, phosphatidylinositol, phosphatidylinositol dimannoside, and some glycolipids. The deoxyribonucleic acid base composition ranges 56 to $58 \mathrm{~mol} \%$ guanine plus cytosine, as determined by the thermal denaturation method (NCTC $10288^{\mathrm{T}}, 58.0 \mathrm{~mol} \%$; NCTC $10284,57.5$ mol\%; NCTC 10285, $56.4 \mathrm{~mol} \%$ ). The type strain is strain NCTC 10288 .

\section{LITERATURE CITED}

1. Collins, M. D., M. Goodfellow, and D. E. Minnikin, 1982. A survey of the structures of mycolic acids in Corynebacterium and related taxa. J. Gen. Microbiol. 128:129-149.

2. Collins, M. D., M. Goodfellow, and D. E. Minnikin. 1982. Fatty acid composition of some mycolic acid-containing coryneform and related bacteria. J. Gen. Microbiol. 128:2503-2509

3. Hill, L. R., S. P. Lapage, and I. S. Bowie. 1978. Computer assisted identification of coryneform bacteria, p. 181-215. In I. J. Bousfield and A. G. Callely (ed.). Coryneform 
bacteria. Academic Press, Inc., London.

4. Jackman, P. J. H. 1982. Classification of Corynebacterium species from axillary skin by numerical analysis of electrophoretic protein patterns. J. Med. Microbiol. 15:485-492.

5. Jones, D. 1975. A numerical taxonomic study of coryneform and related bacteria. J. Gen. Microbiol. 87:52-96.

6. Keddie, R. M., and G. L. Cure. 1977. The cell wall composition and distribution of free mycolic acids in named strains of coryneform bacteria and in isolates from various natural sources. J. Appl. Bacteriol. 42:229-252.

7. Sarkany, I., D. Taplin, and H. Blank. 1961. Erythrasma- common bacterial infection of the skin. J. Am. Med. Assoc. 177:130-134.

8. Sarkany, I., D. Taplin, and H. Blank. 1962. Organism causing erythrasma. Lancet ii:304-305.

9. Sarkany, I., D. Taplin, and H. Blank. 1962. Incidence and bacteriology of erythrasma. Arch. Dermatol. 85:578-582.

10. Skerman, V. B. D., V. McGowan, and P. H. A. Sneath (ed.). 1980. Approved lists of bacterial names. Int. J. Syst. Bacteriol. 30:225-420.

11. Sulea, I. T., M. C. Pollice, and L. Barksdale. 1980. Pyrozine carboxyamidase activity in Corynebacterium. Int. J. Syst. Bacteriol. 30:466-472. 